\title{
Perbandingan Penentuan Waktu Baku Menggunakan Metode Time Study dan Critical Path Method (CPM)
}

\author{
Suci Miranda ${ }^{*}$, Wawan Tripiawan ${ }^{2}$ \\ ${ }^{1} J u r u s a n$ Teknik Industri, Fakultas Teknologi Industri, Universitas Islam Indonesia, Jalan Kaliurang Km. 14,5, Yogyakarta, \\ 55584, Indonesia \\ 2Jurusan Teknik Industri, Fakultas Rekayasa Industri, Telkom University, Jl. Terusan Buah Batu No.01, Sukapura, \\ Dayeuhkolot, Bandung, Jawa Barat, 40257, Indonesia
}

\section{ARTICLE INFORMATION}

Article history:

Received: April 29, 2019

Revised: July 10, 2019

Accepted: July 23, 2019

Kata Kunci:

Critical Path Method

Produktivitas

Time Study

Waktu Baku

\section{A B S T R A K}

Peningkatan perkembangan teknologi mendorong perusahaan maupun industri untuk bisa meningkatkan produktivitasnya. Peningkatan produktivitas tersebut dapat dilakukan dengan perbaikan pada setiap proses yang dijalankan mengikuti waktu baku yang ditetapkan untuk menyelesaikan suatu kegiatan. Penelitian ini bertujuan untuk membandingkan waktu baku pada proses produksi MP YST Revo pada suatu perusahaan pengecoran logam menggunakan metode time study dan pendekatan Critical Path Method (CPM). Kedua metode mengolah informasi yang sama untuk durasi tiap aktivitas dan allowances yang tercatat. Time study menghitung waktu baku proses produksi dengan mempertimbangkan allowances (kelonggaran). CPM menggunakan completion time dan final coefficient dimana penjumlahan durasi tiap aktivitas yang masuk ke jalur kritis (critical path) menjadi completion time. Berdasarkan 4 kali pengamatan, diperoleh rata-rata allowances 30 menit dan rata-rata observed time 450,05 menit. Sementara, CPM memberikan completion time lebih cepat yaitu 341,4 menit. Dalam perhitungan waktu baku, allowances yang dipertimbangkan hanya rest and personal allowances (RPA) diluar jam istirahat seperti minum, istirahat sejenak, dan ke toilet. Terdapat 21 kegiatan dengan dimana 15 diantaranya masuk kepada jalur kritis. Waktu baku menggunakan CPM memberikan selisih sekitar 2 jam lebih cepat dibandingkan time study.

\section{A B S T R A C T}

Increased technological developments encourage companies or industries to be able to increase their productivity. Increased productivity can do with improvements in each process carried out following the standard time set to complete an activity. This study aims to compare the usual time in the production process of MP YST Revo at a metal casting company using the time study method and the Critical Path Method (CPM) approach. Both methods process the same information for the duration of each recorded activity and allowance. The time study calculates the standard time of the production process by considering allowances. The CPM uses completion time and final coefficient where the sum of the duration of each activity entering the critical path becomes completion time. Based on four observations, the average of the 30-minute allowance obtain, and the standard observed time is 450.05 minutes. Meanwhile, CPM gives a faster completion time of 341.4 minutes. In calculating standard time, allowances that are considered only rest and personal allowances (RPA) are outside of breaks such as drinking, short breaks, and to the toilet. There are 21 activities with 15 of them entering the critical path. The standard time to use CPM offers

a difference of about 2 hours faster than a time study.
This is an open access article under the CC-BY-NC-SA license.
Suci Miranda

E-mail: suci.miranda@uii.ac.id 


\section{PENDAHULUAN}

Setiap pemilik perusahaan memacu perusahaannya untuk terus berkembang dengan melakukan perbaikan di setiap proses yang dijalankan. Perbaikan dilakukan bukan hanya memenuhi keinginan konsumen dari segi kualitas produk dan harga yang ditawarkan, tetapi juga agar bagian internal perusahaan dapat menjalankan proses produksi dengan baik sehingga dapat meningkatkan produktivitas perusahaan, dan menghasilkan produk berkualitas bagi konsumen. Perusahaan berusaha memperbaiki proses produksinya agar tetap mampu bersaing dalam bisnisnya [1]. Untuk meningkatkan produktivitas dan mencegah masalah cedera terkait pekerjaan, pekerja harus menyelesaikan pekerjaan dalam waktu yang wajar [2]. Waktu yang wajar juga termasuk kelonggaran waktu istirahat yang tepat agar pekerjaan dilaksanakan tepat waktu. Dalam kaitannya dengan kebutuhan untuk bisnis, tiap sumber harus dapat digunakan secara efisien [3] dengan tujuan untuk meningkatkan produktivitas dalam bisnis. Pengontrolan suatu proses merupakan elemen kunci untuk optimasi produksi [4] untuk menganalisis kinerja proses produksi dan mengusulkan perbaikan guna meningkatkan efisiensinya [5].

Time study merupakan metode yang digunakan untuk strategi peningkatan proses [6] yang digunakan untuk mencatat waktu dan tingkat pelaksanaan operasi tertentu atau elemenelemennya dalam kondisi tertentu, dan pada tingkat kerja yang ditentukan untuk menentukan indeks kinerja individu atau kelompok pekerja, departemen, atau secara keseluruhan [1], [7]. Menurut Nabi, Mahmud, and Islam [8], Time study juga dapat digunakan untuk menganalisis data sehingga diperoleh waktu ideal yang diperlukan operator untuk bekerja pada tingkat kinerja yang ditentukan. Metode time study bertujuan untuk memeriksa pelaksanaan suatu kegiatan, menyederhanakan atau memodifikasi metode operasi untuk mengurangi pekerjaan yang tidak perlu atau berlebihan, pemborosan penggunaan sumber daya, dan menetapkan standar waktu untuk melakukan kegiatan produksi [3].

Time study umumnya digunakan untuk penentuan waktu baku (standard time) [9]. Standard time adalah waktu yang diperlukan untuk menyelesaikan suatu kegiatan/operasi oleh seorang karyawan yang bekerja pada efisiensi $100 \%$ dengan penundaan yang tidak dapat dihindari [10]. Setiap operator memiliki waktu rata-rata untuk melakukan suatu tugas. Akan tetapi ketika waktu baku operator dihitung dan dibandingkan dengan waktu baku perusahaan, didapatkan beberapa operator bekerja lebih lambat dan yang lain lebih cepat [11]. Waktu baku (WB) menjadi indikator utama dalam riset time study yang memprediksi waktu rata-rata seorang pekerja terampil dan terlatih dalam mengerahkan rata-rata usaha melakukan tugas selama jam kerja sesuai dengan metode yang ditetapkan dan kondisi yang ditentukan [10]. Indikator ini dapat digunakan sebagai referensi untuk mengukur dampak perubahan yang dilakukan dalam meningkatkan proses produksi [5]. Penentuan waktu baku yang tidak tepat dapat mempengaruhi produktivitas, operator, dan kualitas diantara metrik lainnya dalam perusahaan [12].

Critical path method (CPM) merupakan salah satu tools yang digunakan pada project scheduling management dimana Schedule atau penjadwalan merupakan salah satu faktor kesuksesan suatu proyek dengan nilai paling tinggi [13], [14]. Critical path adalah serangkaian aktivitas untuk menentukan completion time suatu proyek yang ditentukan berdasarkan waktu minimum penyelesaian suatu proyek [15]. Durasi aktivitas-aktivitas yang termasuk pada jalur kritis dapat mengontrol durasi keseluruhan proyek; penundaan salah satu atau lebih aktivitas pada jalur kritis akan menyebabkan terlambatnya tanggal selesai sebuah proyek. Total waktu yang dibutuhkan untuk menyelesaikan langkah ini adalah lamanya waktu yang dibutuhkan untuk menyelesaikan proyek. Metode jalur kritis (CPM) merupakan alat penjadwalan yang paling banyak digunakan dalam industri [16]. CPM disajikan dalam bentuk diagram jaringan yang diwakili oleh node yang menunjukkan hubungan dan ketergantungan dari kegiatan proyek [17]. CPM pada dasarnya merupakan metode yang berorientasi pada waktu, dalam arti bahwa CPM akan berakhir pada penentuan waktu. Metode ini mengidentifikasi jalur kritis pada aktivitas yang ditentukan ketergantungan antar aktivitasnya [18]. Dari CPM tersebut, dapat dilakukan analisa jaringan kerja, pengurangan,percepatan waktu, serta biaya yang optimal [19].

Metode time study dan CPM mempunyai cara perhitungan yang berbeda beserta keunggulan masing-masing. Namun, belum ditemukan penelitian yang membandingkan keduanya, khususnya pada penentuan waktu baku. Oleh karena itu, penelitian ini bertujuan untuk membandingkan waktu baku pada produksi PM YST Revo menggunakan metode time study dan 
pendekatan CPM. Meskipun keduanya diaplikasikan di bidang yang berbeda, time study berkaitan dengan ergonomi dan CPM untuk project management, mereka dapat saling melengkapi dalam hubungannya dengan peningkatan produktivitas. Identifikasi jalur kritis pada CPM dapat membantu perusahaan mempersiapkan mitigasi pada kegiatan yang kritis sekaligus menetapkan waktu penyelesaian pekerjaan. Dengan menentukan waktu baku pada proses produksi, perusahaan dapat menstandarkan waktu pengerjaan tiap proses termasuk guna menjaga keberlangsungan standarisasi proses produksi.

\section{METODE PENELITIAN}

Produk yang menjadi objek penelitian adalah produk MP YST Revo (Gambar 1), karena merupakan produk yang memiliki tingkat pemesanan yang paling tinggi.

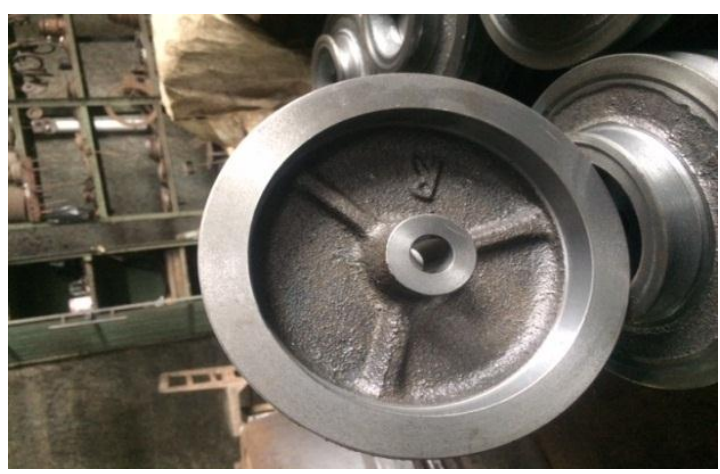

Gambar 1. MP YST Revo

\section{Time Study}

Perhitungan time study sesuai dengan langkah penelitian berikut ini (Gambar 2).

1. Mengidentifikasi proses produksi MP YST Revo melalui wawancara dengan kepala produksi.

2. Mengumpulkan semua informasi terkait situasi kerja, operator, pekerjaan yang dapat mempengaruhi perhitungan waktu baku. Misal, situasi kerja di luar atau di dalam ruangan dan jumlah pekerja.

3. Mengamati waktu untuk tiap langkah dalam proses produksi termasuk kondisi kerja dengan 4 (empat) kali pengamatan di waktu dan operator yang berbeda, masing-masing 2 pengamatan di pagi dan sore hari. Pengamatan dilakukan menggunakan metode umum pengukuran manual stopwatch time study.
4. Menghitung waktu normal (normal time) berdasarkan observed time (OT), performance rating factor (PRF), dan process allowances (PA).

Observed time (OT) diperoleh berdasarkan waktu siklus (cycle time) yaitu total waktu yang dibutuhkan untuk menyelesaikan suatu kegiatan. Dalam hal ini yang diamati adalah operator cycle time. Performance rating factor (PRF) merupakan faktor penyesuaian yang menggambarkan nilai kecepatan efektif operator berdasarkan konsep pengamat tentang "kecepatan normal" dalam mengerjakan tiap langkah proses produksi. Sementara, process allowances (PA) yang mengakibatkan penundaan kecil yang tak terhindarkan dan pekerjaan ekstra kecil yang sesekali muncul seperti mesin tidak bekerja dengan baik atau berhenti, listrik mati dalam waktu yang tidak lama, alat rusak, atau mengambil suatu peralatan yang diperlukan dari tempatnya.

Dalam menentukan waktu normal menggunakan tiga tipe waktu observasi yaitu optimum time (OT), most likely time (MLT), dan pessimistic time (PT) [2]. Metode ini juga dipakai di penjadwalan proyek dengan istilah PERT (Project Evaluation and Review Technique). Ketiga waktu tersebut dihitung dan disebut dengan expected time (ET). Metode 3 waktu dapat dijadikan sebagai benchmark waktu yang paling cepat dan paling lama dibutuhkan untuk menyelesaikan suatu pekerjaan. Optimistic time (OT) adalah waktu yang dibutuhkan ketika semua faktor kondisi kerja dan operator dalam keadaan terbaik Sebaliknya Pessimistic time (PT) adalah saat kondisi pekerjaan tidak baik, misalnya cuaca berdebu. Most likely time (MLT) diukur saat kondisi umum. Hal ini menunjukkan bahwa metode penjadwalan 3 waktu di project management dapat diadopsi untuk menentukan waktu baku suatu proses produksi. Namun, pada penelitian ini, ketiga waktu tersebut tidak diukur mengingat keterbatasan tempat penelitian pengecoran logam.

Normal time disebut juga sebagai corrected time. Dalam mengerjakan suatu proses, tiap operator memiliki tingkat kecepatan yang berbeda-beda [20]. Kecepatan yang diperagakan oleh operator selama time study dinilai atau dievaluasi oleh time study observer dan waktu yang dipilih disesuaikan 
Time Study

1. Mengidentifikasi proses produksi

2. Mengumpulkan data dan semua informasi terkait situasi kerja dan operator

3. Mencatat waktu (observed time) tiap proses dan "kecepatan normal"

4. Menghitung waktu normal

5. Mencatat kelonggaran (allowances) selama proses produksi

6. Menghitung waktu baku (standard time)

Critical Path Method

1. Menentukan predecessor tiap proses

2. Memasukkan proses produksi dan waktu ke Ms. Project software

3. Menentukan jalur kritis (critical path) dengan bantuan software

4. Menghitung completion time

Membandingkan waktu baku

Gambar 2. Aliran penelitian

dengan faktor penilaian, sehingga operator yang berkualifikasi, bekerja pada kecepatan normal, dapat dengan mudah melakukan pekerjaan dalam spesifikasi yang ditentukan. Untuk menormalkan waktu kerja yang diperoleh dari pengukuran waktu kerja akibat kerja operator yang berubah-ubah, maka digunakan Performance Rating Factor (PRF). Pada penelitian ini, digunakan PRF 1 yaitu operator bekerja secara wajar dalam keadaan normal [10]. Berdasarkan Westing-house system [10], terdapat 4 (empat) faktor yang dipertimbangkan dalam menghitung PRF: skill, effort, conditions, dan consistency.

Rumus waktu normal adalah sebagai berikut:

$$
\text { Waktu Normal }=\text { Observed Time } \times \text { Rating }
$$

Faktor penyesuaian dibagi menjadi 3 (10):

$\mathrm{P}=1$ (operator bekerja secara wajar)

$\mathrm{P}<1$ (operator bekerja terlalu lambat)

$P>1$ (operator bekerja terlalu cepat)

5. Mencatat allowances seperti rest and personal allowances (RPA), special allowances $(S A)$, dan policy allowances (PoA) [21].

Allowances dalam time study didefinisikan sebagai waktu tambahan yang akan ditambahkan ke waktu dasar operasi untuk memperhitungkan keinginan personil, keterlambatan, kelelahan operator, setiap situasi khusus, dan kebijakan perusahaan atau organisasi. Waktu baku (standard time, ST) suatu pekerjaan diperoleh dengan menambahkan berbagai allowances ke waktu dasar atau normal pekerjaan itu. Terdapat beberapa allowances seperti Special Allowances, Fixed Allowances, Variable Allowances, Rest and Personal Allowances, dan Policy Allowances [21]. Kelonggaran atau allowances ini dipertimbangkan untuk memberikan kompensasi kepada operator atas gangguan produksi yang mungkin terjadi,operator memerlukan kebutuhan yang sah, atau faktor-faktor di luar kendalinya. Sebagai contoh, keterlambatan dapat terjadi karena kebutuhan operator seperti air minum, pergi ke toilet, dan sebagainya. Penundaan yang lain juga tak dapat terhindarkan seperti menunggu alat, bahan atau peralatan, pemeliharaan mesin, dan inspeksi berkala terhadap bagian/bahan. Pada penelitian ini, hanya RPA (Rest and Personal Allowances) yang dapat diidentifikasi dikarenakan perusahaan belum memiliki standar operasional perusahaan (SOP) untuk proses produksi MP YST Revo. Tekanan fisik, fokus mental tertentu yang dibutuhkan dalam mengerjakan suatu aktivitas, temperatur, intensitas cahaya, debu, suara, dan sebagainya tidak diperhitungkan dalam menentukan allowances. Untuk kondisi tertentu, seorang pekerja mungkin membutuhkan level allowances lebih tinggi [2]. Sebagai contoh, seorang pekerja yang memakai kacamata dapat membutuhkan allowances ekstra dibandingkan dengan yang tidak menggunakannya.

Rest and personal allowances (RPA) termasuk merokok, mencuci tangan, pergi ke kamar mandi, dan minum air. Special allowances (SA) terjadi untuk waktu yang sementara, termasuk start up dan shut down mesin, waktu set up mesin baru, dan produk rework (dikerjakan ulang). Sedangkan PoA berasal dari kebijakan perusahaan dan bersifat sementara untuk pekerjaan tertentu.

6. Komponen utama dalam menghitung waktu baku ditunjukkan di Gambar 3 terdiri dari 
observed time, PRF, allowances (relaxation, contingency and interference, dan policy) [21] Menghitung waktu baku mengikuti rumus:

WB $=$ Waktu Normal $\times(1+$ Allowances $)$

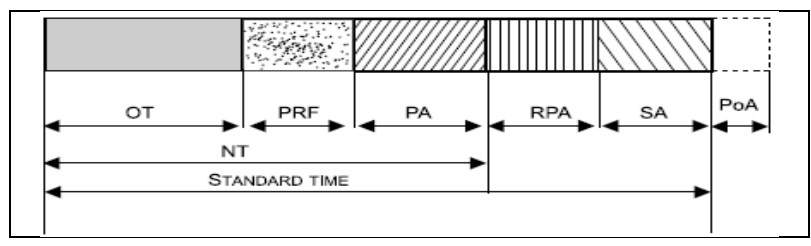

Gambar 3. Komponen Waktu Baku

\section{Critical Path Method (CPM)}

Perhitungan CPM dibantu dengan Ms. Project 2016 software. Tools ini memudahkan dalam membuat network diagram, menghitung earliest start, earliest finish, latest start, dan latest finish untuk waktu penyelesaian proses produksi, dan menghitung slack yang dibutuhkan dalam menghitung completion time. Istilah completion time di CPM, pada penelitian ini, diasumsikan setara dengan waktu normal dimana waktu baku pada time study merupakan waktu normal ditambah dengan allowances (kelonggaran). Langkah CPM adalah sebagai berikut [21]:

1. Menentukan predecessor atau kegiatan yang mendahului. Didapatkan dari wawancara dengan kepala produksi.

2. Semua informasi seperti proses produksi, durasi tiap proses, dan predecessors diolah menggunakan software untuk menghitung early start, early finish, late start, dan late finish. Durasi tiap proses menggunakan data yang sama yang didapatkan dari observed time di time study sebelumnya.

3. Menentukan jalur kritis dan completion time completion time merupakan penjumlahan durasi dari proses yang masuk ke dalam jalur kritis.

4. Perhitungan waktu baku menggunakan rumus berikut [21]:

Final coefficient $=1+$ allowances WB $=$ completion time $\times$ final coefficient

Waktu baku dari kedua metode kemudian dibandingkan dan dianalisis dengan proses yang masuk ke dalam jalur kritis.

\section{HASIL DAN PEMBAHASAN}

Penelitian ini dilakukan di perusahaan yang bergerak dalam bidang pengecoran logam di Ceper, Klaten. Sistem perencanaan produksi pada MP YST Revo merupakan tipe make to order. Berdasarkan wawancara dengan operator di bagian proses produksi MP YST Revo, mereka dapat mencetak rata-rata 50 produk dalam sehari atau sekitar 200-250 produk setiap minggu. Dalam proses penerimaan karyawan untuk bagian produksi, level pendidikan yang tinggi tidak dibutuhkan. Hal utama yang diperhatikan adalah karyawan dapat mengerjakan tugas yang diberikan sehingga dalam proses produksi pun semuanya dilakukan berdasarkan keinginan karyawan tanpa ada aturan yang jelas terkait waktu pengerjaan setiap produk. Kondisi tersebut disebabkan karena pada dasarnya memang belum terdapat aturan jelas yang dibuat oleh perusahaan terkait standard operasional procedure (SOP) dalam melakukan produksi, sehingga sulit untuk menilai peningkatan produktivitas dan efisiensi kerja.

Dari proses produksi MP YST Revo tersebut dilakukan pengamatan waktu baku produksi untuk dijadikan dasar dan pedoman dalam pembuatan SOP di perusahaan. Pengamatan dimulai di bagian produksi, sejak bahan baku masuk lantai produksi hingga proses menunggu untuk diangkut ke dalam truk. Dalam menghitung waktu produksi, peneliti mengabaikan employee skill seperti tingkat pendidikan dan lama bekerja. Begitu juga pada perhitungan completion time, constraints seperti risiko tiap proses dan biaya diabaikan karena kedua batasan ini dapat mempengaruhi penentuan durasi tiap aktivitas. Faktor penyesuaian (PRF) yang digunakan pada penelitian ini adalah 1, yang artinya operator bekerja secara wajar tidak terlalu lambat ataupun terlalu cepat.

Berdasarkan hasil wawancara dengan kepala produksi, berikut proses produksi MP YST Revo yang ditunjukkan pada Gambar 4:

1. Proses pengambilan material

Proses pemindahan material dilakukan dari gudang penyimpanan ke kendaraan pengangkut bahan baku. Proses ini dilakukan seorang operator dengan 1 (satu) kendaraan pengangkut yang dapat memuat sekitar 50-60 $\mathrm{Kg}$ bahan baku.

2. Pengangkutan material Material dipindahkan dari gudang menuju stasiun peleburan dengan jarak $5 \mathrm{~m}$ dari gudang penyimpanan.

3. Pengumpulan limbah besi cor

Bahan baku yang telah diangkut, dikumpulkan bersama limbah besi yang lain untuk dilelehkan atau dileburkan.

4. Proses peleburan

Proses peleburan yaitu melelehkan besi logam dan bahan pendukung lainnya dengan 2 (dua) lapis komponen yaitu besi dan baja. Logam dan bahan pendukung lain seperti 
scrap yang telah menjadi cairan akan digunakan untuk proses pengecoran.

5. Pembuatan cetakan pasir

Pada dasarnya, selain cetakan pasir diperlukan juga sebuah pola cetakan untuk membuat cetakan pasir yang terbuat dari kayu ataupun aluminium tergantung presisi yang dibutuhkan, hanya saja proses pembuatan pola ini tidak terekam prosesnya oleh peneliti. Proses pembuatan cetakan pasir dilakukan bersamaan dengan proses peleburan, sehingga ketika logam telah cair dapat langsung dituangkan ke dalam cetakan. Cetakan pasir ini diberikan slag agar logam mudah dilepaskan.

6. Pengangkutan dan pengambilan cairan logam Proses ini merupakan satu kesatuan proses. Cairan logam diangkut dari stasiun peleburan menuju stasiun pencetakan dan karyawan menunggu untuk mengantri mengambil cairan logam untuk diisikan ke dalam cetakan pasir yang telah dibuat. Dalam sekali pengangkutan, diangkut 1 (satu) tapping cairan logam seberat $500 \mathrm{~kg}$ untuk semua jenis produk yang dibuat.

7. Pengecoran

Logam yang diambil kemudian dituangkan kedalam cetakan pasir untuk membentuk produk yang diinginkan. Proses ini berlangsung beberapa jam untuk menunggu hingga logam terbentuk.

8. Pembongkaran cetakan

Merupakan proses mengeluarkan logam yang telah di cor dari cetakan pasir sehingga pasir tersebut dapat digunakan kembali untuk pencetakan.

9. Pendinginan

Mendinginkan logam sebelum diangkut untuk dibersihkan, logam didinginkan untuk membantu karyawan dalam proses pengangkutan serta untuk memastikan bahwa logam benar siap untuk diangkut. Setelah dingin, dilakukan quality control pada produk. Jika tidak terdapat cacat maka dapat dilanjutkan ke pencucian. Namun jika produk cacat maka kembali dileburkan.

10. Pembersihan/pencucian

Setelah dingin, maka produk diangkut menuju stasiun pembersihan dengan jarak sejauh $15 \mathrm{~m}$ dari stasiun pencetakan yang dilakukan oleh 1 (satu) orang pekerja. Proses pembersihan menggunakan mesin pembersih untuk produk ukuran kecil dengan kapasitas $300 \mathrm{~kg}$. Tujuan dari proses ini untuk membersihkan sisa pasir atau bekasbekas pencetakan. Setelah dilakukan pembersihan, produk dicek kualitasnya jika terdapat cacat produk atau produk yang belum bersih maka dilakukan pembersihan lagi. Jika produk sudah bersih maka diangkut ke stasiun permesinan.

11. Merapikan bentuk

Merapikan bentuk ini menggunakan mesin yang dioperasikan oleh seorang pekerja untuk membuat produk lebih halus dan mulus lagi agar sesuai dengan presisi yang diinginkan mengikuti detail-detail yang telah ditentukan. Setelah itu dilakukan pemeriksaan hasil permesinan. Jika belum sesuai maka dikembalikan ke permesinan. Jika telah sesuai dilanjutkan pada pencelupan untuk mencegah produk tersebut berkarat. Quality control dan pencelupan produk dilakukan oleh seorang operator yang sama.

\section{Perhitungan Waktu Baku}

Dalam menentukan waktu baku proses produksi MP YST Revo, dibutuhkan data observed time (OT), allowances, dan waktu normal (normal time, NT) [21]-[23]. Untuk mengetahui durasi tiap proses, maka dilakukan pengamatan menggunakan stop watch sebanyak 4 kali terhadap 15 operator proses produksi (Tabel 1): pengamatan 2 dan 3 diambil saat siang hari setelah pekerja beristirahat. Pengamatan 1 dan 4 dilakukan di pagi hari. Untuk menghasilkan rata-rata 50 produk per hari, operator melakukan kegiatan peleburan/pelelehan sebanyak 2 kali. Hal ini mendukung pengamatan yang dapat dilakukan pagi dan siang hari. Allowances (kelonggaran) yang tercatat, diluar jam istirahat, untuk keempat pengamatan adalah sebagai berikut secara berurutan: 40 menit, 20 menit, 25 menit, dan 35 menit. Allowances digunakan operator untuk minum, istirahat sejenak, dan ke toilet.

Observed time dilakukan sebanyak 4 (empat) kali untuk membandingkan waktu yang dibutuhkan tiap aktivitas sekaligus memastikan bahwa waktu perekaman setiap aktivitas dicatat dengan benar [22]. Rata-rata waktu siklus atau observed time (OT) berdasarkan empat pengamatan adalah 450,05 menit. Process allowances (PA) diabaikan, artinya tidak terjadi hal yang mengganggu proses produksi. Untuk studi ini, PRF (performance rating factor) diasumsikan 1 yaitu operator tidak bekerja terlalu lambat atau terlalu cepat [10]. Atau dengan kata lain, observed performance dan normal performance adalah dalam waktu yang sama. Hal ini dikarenakan perusahaan belum memiliki waktu untuk tiap proses. Berdasarkan rumus 1, waktu 


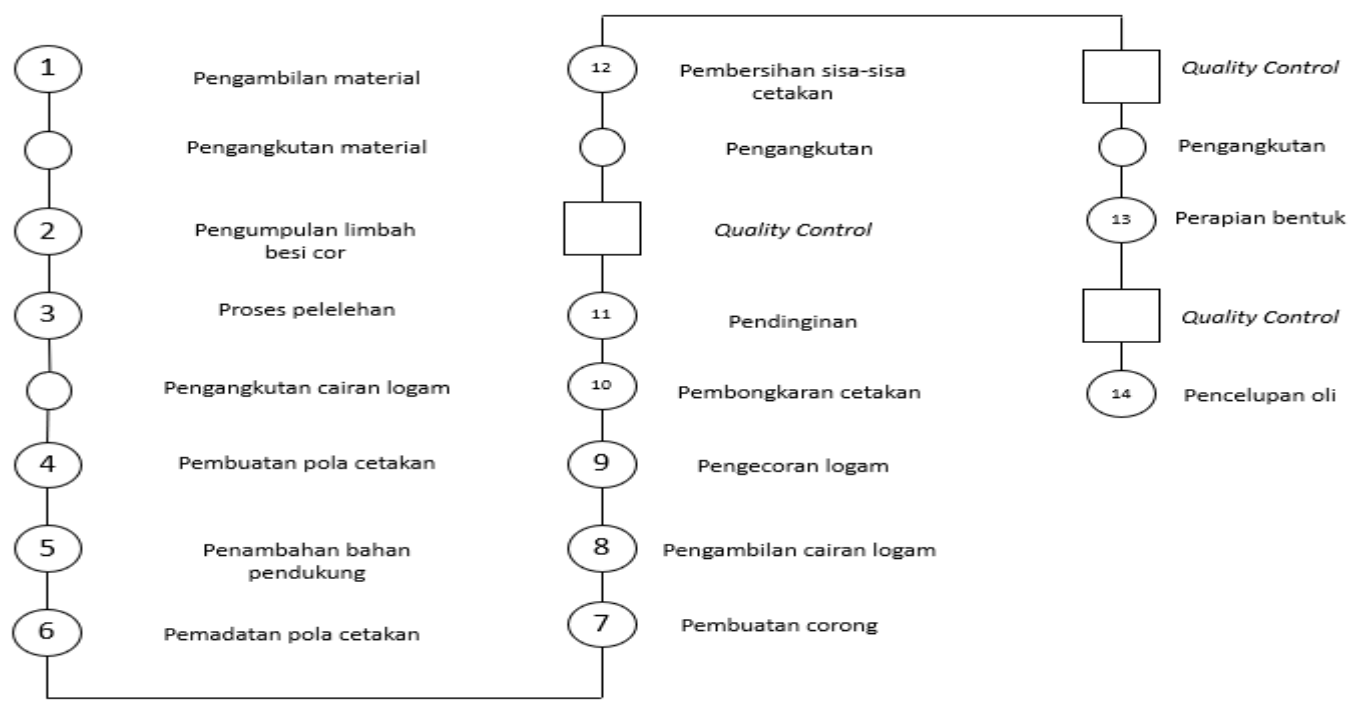

Gambar 4. Process Chart Produksi MP YST Revo

normal (normal time, NT) adalah:
Waktu Normal $=$ Observed Time $\times$ Rating $=450,05$ menit $\times 1$$$
=450,05 \text { menit }
$$

Berdasarkan perhitungan kecukupan data, 4 pengamatan sudah mewakili data untuk perhitungan waktu baku.

$\mathrm{N}^{\prime}=\left[\frac{\sqrt[k]{\sqrt{N \Sigma x^{2}-\sum x^{2}}}}{\sum x}\right]^{2}$

\section{Keterangan:}

$$
\begin{array}{ll}
\mathrm{K} & =\text { Tingkat keyakinan }(90 \% \approx 2) \\
\mathrm{S} & =\text { Derajat ketelitian } \\
\mathrm{N} & =\text { Jumlah data pengamatan } \\
\mathrm{N}^{\prime} & =\text { Jumlah data teoritis } \\
\mathrm{X} & =\text { Data pengamatan }
\end{array}
$$

Diketahui:

$$
\begin{array}{ll}
\mathrm{N} & =4 \\
\mathrm{~S} & =10 \% \\
\mathrm{k} & =2 \\
\mathrm{X} & =450,05 \text { menit } \\
\mathrm{X}^{2} & =202.545 \text { menit } \\
\sum \mathrm{x}^{2} & =815.644 .96 \text { menit } \\
\sum \mathrm{x} & =1.803,2 \text { menit } \\
\left(\sum \mathrm{x}\right)^{2} & =3.251 .530,2 \text { menit } \\
\mathrm{N} \Sigma \mathrm{x}^{2} & =4 \times 815.644,96 \text { menit } \\
& =3.262 .579,83 \text { menit }
\end{array}
$$

$$
\begin{aligned}
& N^{\prime}=\left[\frac{k / s \sqrt{\mathrm{N} \sum x^{2}-\left(\sum x\right)^{2}}}{\sum x}\right]^{2} \\
& N^{\prime}=\left[\frac{20 \sqrt{3.262 .579,83-3.251 .530,2}}{1.803,2}\right]^{2} \\
& N^{\prime} \quad=1,36 \\
& N^{\prime}<\mathrm{N} \quad=1,36<4 \text { (Cukup) }
\end{aligned}
$$

Berdasarkan Tabel 1 observed time operator mengerjakan keseluruhan proses produksi tanpa allowances setara dengan 7,5 jam. Allowances 30 menit adalah $6.7 \%$ dari total waktu kerja per hari (8 jam kerja). Sehingga, dengan menggunakan rumus (2) diperoleh waktu baku:

$$
\begin{aligned}
\text { Waktu baku } & =450,05 \text { menit } \times(1+0.67) \\
& =480,05 \text { menit atau setara } 8 \text { jam }
\end{aligned}
$$

Jika merujuk kepada waktu bekerja dari jam 8 pagi hingga 5 sore dengan waktu istirahat selama 1 jam (12.00 - 13.00), waktu baku yang dihitung merupakan jam kerja operator seharihari. Namun, tidak jarang proses produksi belum dapat diselesaikan dalam waktu tersebut sehingga dilanjutkan keesokan harinya. Seperti terlihat di Tabel 1, hampir seluruh aktivitas di masing-masing pengamatan dilakukan dengan waktu yang relatif sama. Terdapat 3 aktivitas yang memiliki perbedaan waktu pengerjaan cukup signifikan sekitar 10 menit untuk proses pelelehan, pengecoran logam, dan pendinginan. 
Tabel 1. Proses Produksi dan Waktu Pengamatan

\begin{tabular}{|c|c|c|c|c|c|c|c|c|}
\hline \multirow{2}{*}{ ID } & \multirow{2}{*}{ Jenis kegiatan } & \multirow{2}{*}{ Predecessor } & \multirow{2}{*}{ Operator } & \multicolumn{5}{|c|}{ Waktu Pengamatan (menit) } \\
\hline & & & & 1 & 2 & 3 & 4 & $\begin{array}{c}\text { Rata- } \\
\text { rata }\end{array}$ \\
\hline & Persiapan bahan baku & & 1 & & & & & \\
\hline 1 & Pengambilan material & & & 30 & 30 & 28 & 30 & 29,5 \\
\hline \multirow[t]{2}{*}{2} & Pengangkutan material & 1 & & 90 & 90 & 90 & 90 & 90 \\
\hline & Pembuatan Cairan Logam & & 4 & & & & & \\
\hline 3 & Pengumpulan limbah besi cor & & & 15 & 13 & 13 & 15 & 14 \\
\hline 4 & Proses pelelehan & 1,3 & & 180 & 160 & 160 & 172 & 168 \\
\hline \multirow[t]{2}{*}{5} & Pengangkutan & 4 & & 4 & 2 & 2 & 3 & 2,75 \\
\hline & Pembuatan Cetakan & & 1 & & & & & \\
\hline 6 & Pembuatan pola cetakan & & & 2,03 & 2,03 & 2 & 2 & 2,015 \\
\hline 7 & Penambahan bahan pendukung & 6 & & 1,5 & 1,5 & 1,5 & 0,5 & 1,25 \\
\hline 8 & Pemadatan pola cetakan & 7 & & 0,5 & 0,5 & 1,5 & 0,5 & 0,75 \\
\hline \multirow[t]{2}{*}{9} & Pembuatan corong & 8 & & 0,67 & 0,67 & 0.5 & 0,67 & 0,675 \\
\hline & Pencetakan & & 1 & & & & & \\
\hline 10 & Pengambilan cairan logam & 5,9 & & 4 & 2 & 2,67 & 3 & 2,917 \\
\hline \multirow[t]{2}{*}{11} & Pengecoran logam & 10 & & 100 & 81 & 80 & 97 & 89,5 \\
\hline & Pembongkaran cetakan pasir & & 2 & & & & & \\
\hline 12 & Pembongkaran cetakan & 11 & & 0,33 & 0,33 & 0,33 & 0,33 & 0,33 \\
\hline 13 & Pendinginan & 12 & & 30 & 19 & 20 & 27 & 24 \\
\hline \multirow[t]{2}{*}{14} & Quality control & 13 & & 2 & 2 & 2 & 2 & 2 \\
\hline & Pembersihan & & 3 & & & & & \\
\hline 15 & Pengangkutan & 14 & & 4 & 3 & 3 & 3 & 3,25 \\
\hline 16 & Pembersihan sisa-sisa cetakan & 15 & & 5 & 3,67 & 2 & 4 & 3,667 \\
\hline \multirow[t]{2}{*}{17} & Quality control & 16 & & 2 & 3 & 3 & 3 & 2.75 \\
\hline & Permesinan & & 2 & & & & & \\
\hline 18 & Pengangkutan & 17 & & 3 & 2 & 2 & 2 & 2,25 \\
\hline \multirow[t]{2}{*}{19} & Perapian bentuk & 18 & & 8,3 & 7 & 7 & 7 & 7,325 \\
\hline & Finishing & & 1 & & & & & \\
\hline 20 & Quality control & 19 & & 2 & 1 & 1 & 1,67 & 1,417 \\
\hline \multirow[t]{3}{*}{21} & Pencelupan pada oli & 20 & & 2 & 1 & 2 & 2 & 1,75 \\
\hline & TOTAL (menit) & & & 486,33 & 424,7 & 423,5 & 465,67 & 450,05 \\
\hline & ALLOWANCES (menit) & & & 40 & 20 & 25 & 35 & 30 \\
\hline
\end{tabular}

\section{Critical Path Method}

Semua aktivitas merupakan jenis kegiatan Finish-to-Start (FS) berdasarkan pendekatan CPM kecuali membuat cetakan yang terlihat di Tabel 1. Sebagai contoh, aktivitas pelelehan dapat dilakukan (Start) jika aktivitas mengumpulkan limbah besi cor sudah selesai (Finish). Pada aktivitas pengambilan cairan logam, terdapat 2 aktivitas sebelumnya atau yang mendahuluinya yaitu pengangkutan cairan logam dan membuat cetakan pasir. Hasil perhitungan waktu baku akan dibandingkan dengan completion time menggunakan pendekatan critical path method (metode dalam project management). Untuk mendapatkan completion time, digambarkan network diagram seperti ditunjukkan pada Gambar 5 untuk mengetahui Earliest Start (ES), Earliest Finish (FS), Latest Start (LS), dan Latest Finish ( LF). Informasi ini akan digunakan untuk menghitung Slack tiap aktivitas. Bagi aktivitas yang memiliki Slack 0 maka merupakan jalur kritis (critical path). Slack atau fleksibilitas jadwal diukur dengan jumlah waktu suatu jadwal aktivitas dapat ditunda atau diperpanjang dari tanggal mulai awal tanpa menunda tanggal penyelesaian proyek atau melanggar batasan jadwal [23]. Slack didapatkan dari pengurangan LS - ES atau 


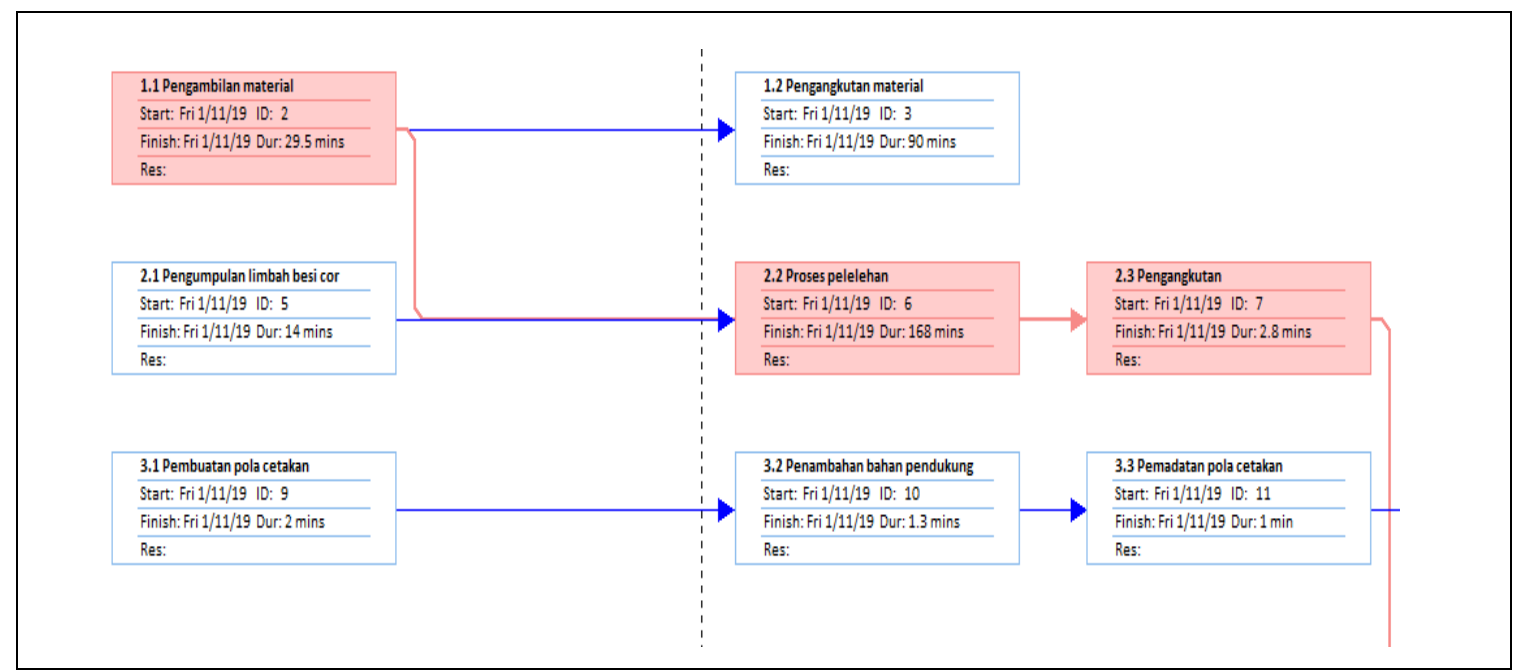

Gambar 5. Contoh Network Diagram dari Ms. Project

Tabel 2. Critical Path

\begin{tabular}{|c|c|c|c|}
\hline Task Name & Predecessors & Duration & Total Slack \\
\hline 1. Persiapan Bahan Baku & & 119,5 menit & 0 menit \\
\hline 1.1 Pengambilan Material & & 29,5 menit & 0 menit \\
\hline 1.2 Pengangkutan Material & 2 & 90 menit & 222,8 menit \\
\hline 2. Pembuatan Cairan Logam & & 200,3 menit & 0 menit \\
\hline 2.1 Pengumpulan limbah besi cor & & 14 menit & 15,5 menit \\
\hline 2.2 Proses pelelehan & 2,5 & 168 menit & 0 menit \\
\hline 2.3 Pengangkutan & 6 & 2,8 menit & 0 menit \\
\hline 3. Pembuatan Cetakan & & 5,3 menit & 195 menit \\
\hline 3.1 Pembuatan pola cetakan & & 2 menit & 195 menit \\
\hline 3.2 Penambahan bahan pendukung & 9 & 1,3 menit & 195 menit \\
\hline 3.3 Pemadatan pola cetakan & 10 & 1 menit & 195 menit \\
\hline 3.4 Pembuatan corong & 11 & 1 menit & 195 menit \\
\hline 4. Pencetakan & & 92,4 menit & 0 menit \\
\hline 4.1 Pengambilan cauran logam & 7,12 & 2,9 menit & 0 menit \\
\hline 4.2 Pengecoran logam & 14 & 89,5 menit & menit \\
\hline 5. Pembongkaran cetakan pasir & & 27 menit & 0 menit \\
\hline 5.1 Membongkar cetakan & 15 & 1 menit & 0 menit \\
\hline 5.2 Pendinginan & 17 & 24 menit & 0 menit \\
\hline 5.3 Quality Control & 8 & 2 menit & menit \\
\hline 6. Pembersihan & & 9,8 menit & menit \\
\hline 6.1 Pengangkutan & 19 & 3,3 menit & menit \\
\hline 6.2 Membersihkan sisa-sisa cetakan & 21 & 3,7 menit & menit \\
\hline 6.3 Quality Control & 22 & 2,8 menit & menit \\
\hline 7. Permesinan & & 9,6 menit & menit \\
\hline 7.1 Pengangkutan & 23 & 2,3 menit & menit \\
\hline 7.2 Merapikan Bentuk & 25 & 7,3 menit & menit \\
\hline 8. Finishing & & 3,2 menit & menit \\
\hline 8.1 Quality Control & 26 & 1,4 menit & menit \\
\hline 8.2 Pencelupan pada oli & 28 & 1,8 menit & 0 menit \\
\hline
\end{tabular}


LF - EF. Keduanya akan memberikan hasil yang sama sehingga dapat dipilih salah satu dalam mencari nilai Slack.

Penjumlahan durasi tiap aktivitas pada jalur kritis merupakan completion time proses tersebut. Agar memudahkan perhitungan, studi ini dibantu oleh software Ms. Project 2016. Jalur kritis pada Gambar 5 diwakili oleh warna merah. Berdasarkan Tabel 2, hampir semua aktivitas masuk ke dalam jalur kritis (warna kuning di tabel). Terdapat 15 dari 21 aktivitas yang memiliki Slack 0 adalah: pengambilan material (29,5 menit), proses pelelehan (168 menit), pengangkutan (2,8 menit), pengambilan cairan logam (2,9 menit), pengecoran logam (89,5 menit), pembongkaran cetakan (1 menit), pendinginan (24 menit), quality control di pembongkaran cetakan pasir (2 menit), pengangkutan (3,3 menit), pembersihan sisa-sisa cetakan (3,7 menit), quality control di pembersihan (2,8 menit), pengangkutan (2,3 menit), merapikan bentuk (7,3 menit), quality control di finishing (1,4 menit), dan pencelupan pada oli (1,8 menit) dengan completion time yaitu 341,4 menit atau sekitar 5,5 jam.

Tabel 3. Perbandingan Time Study dan CPM

\begin{tabular}{lcc}
\hline & Time Study & CPM \\
\hline $\begin{array}{l}\text { Observed time } \\
\text { (OT) }\end{array}$ & 450,05 menit & 341,4 menit \\
PRF 1 & & \\
Normal time & 450,05 menit & 341,4 menit \\
(NT) = OT x 1 & & \\
Allowances & 30 menit & 30 menit \\
$\begin{array}{l}\text { Allowances } \\
\text { factor (AF) }\end{array}$ & $6.7 \%$ & $6.7 \%$ \\
$\begin{array}{l}\text { Standard time } \\
\text { (ST) }=\end{array}$ & 480,05 menit & 371,4 menit \\
(NT)(1+AF) & & \\
\hline
\end{tabular}

Di Ms. Project 2016, waktu proses pembongkaran cetakan sebenarnya adalah 0,33 menit namun dibaca menjadi 1 menit. Begitu juga untuk pembersihan sisa-sisa cetakan, waktu yang diolah dari 3,677 menjadi 3,7 menit. Hal ini dikarenakan software tidak dapat membaca 2 angka di belakang koma tetapi dibulatkan menjadi hanya 1 angka di belakang koma. Waktu yang dimasukkan kedalam software merupakan rata-rata dari keempat pengamatan untuk tiap aktivitas seperti yang terlihat pada Tabel 1.

Persentase kelonggaran (allowances) yang diperkenankan oleh suatu perusahaan sangat beragam, mulai dari yang terkecil $5 \%$ dari jam kerja hingga yang tertinggi 30\% [22]. Pada penelitian ini, allowances 30 menit merupakan $6,7 \%$ dari 8 jam kerja (480 menit). Berdasarkan rumus (3), 341,4 merupakan completion time menggunakan CPM yang diasumsikan sebagai observed time pada time study. Kemudian, masing-masing observed dan completion time dikalikan dengan PRF 1. Berdasarkan Tabel 3 diperoleh CPM memberikan waktu baku lebih cepat 2 jam dibandingkan dengan time study.

Perhitungan completion time tidak hanya dipengaruhi oleh durasi tiap aktivitas namun juga jumlah tenaga kerja yang tersedia, risiko tiap aktivitas, dan biaya yang dimiliki perusahaan dalam mengerjakan proses produksi yang disebut sebagai constraints [23]. Kondisi ideal, semua variabel tersebut dihitung untuk tiap aktivitas agar mendapatkan completion time yang akurat. Sementara dari sisi time study, waktu baku dipengaruhi oleh variabel allowances. Kedua metode ini bertujuan untuk memberikan kelonggaran dalam menentukan waktu baku pengerjaan suatu aktivitas, meskipun metrik kelonggaran yang dipertimbangkan berbeda. Sebagai contoh, menggunakan CPM, durasi aktivitas $\mathrm{A}$ ditentukan oleh jumlah tenaga kerja yang dimiliki. Semakin banyak yang tersedia maka akan semakin cepat pengerjaan aktivitas tersebut. Sedangkan terkait tenaga kerja, aktivitas A akan memperhatikan skill yang dimiliki [10] jika menggunakan metode time study.

Metode CPM memberikan hasil perhitungan waktu baku 2 jam lebih cepat dibandingkan dengan time study. Penyebab utama adalah cara perhitungan yang berbeda di kedua metode tersebut. Observed time merupakan akumulasi dari rata-rata durasi tiap aktivitas sesuai dengan jumlah pengamatan yang dilakukan. Pada penelitian ini, terdapat 21 aktivitas dengan ratarata observed time adalah 450,05 menit. Normal time kemudian dikalikan dengan PRF yang dalam penelitian ini diasumsikan 1 (operator bekerja dalam kecepatan normal). Sementara pada CPM, 341,4 menit merupakan penjumlahan durasi aktivitas yang masuk kedalam jalur kritis (critical path) dimana aktivitas tersebut memiliki slack 0. Berdasarkan Tabel 2, 15 dari 21 aktivitas masuk ke dalam jalur kritis. Sehingga, durasi dari 15 aktivitas tersebut menjadi completion time.

Seperti yang telah dijelaskan sebelumnya, terdapat 6 (enam) aktivitas yang bukan merupakan jalur kritis dengan total waktu 109,3 menit. Jika dijumlahkan 341,4 menit dan 109,3 
menit menjadi 450,7 menit. Artinya bahwa ada selisih 109,3 menit antara metode time study dan CPM dimana selisih waktu tersebut adalah aktivitas yang tidak masuk ke dalam jalur kritis menurut perhitungan CPM. Keenam aktivitas di luar jalur kritis dapat mengalami penundaan atau keterlambatan dalam pengerjaannya dan penundaan tersebut tidak akan mempengaruhi completion time yang telah dihitung, berdasarkan pengertian CPM. Namun, completion time dan jalur kritis dapat berubah jika constraints dimasukkan dalam perhitungan. Pada penelitian ini, hanya informasi durasi tiap aktivitas yang diolah oleh software. Yang perlu dicatat adalah informasi durasi waktu tiap aktivitas yang diolah baik menggunakan metode time study dan CPM adalah sama, berikut dengan data allowances. Namun, karena konsep perhitungan yang berbeda menyebabkan perbedaan hasil akhir perhitungan waktu baku untuk proses produksi yang sama.

Kedua metode ini dapat memberikan informasi yang saling mendukung dalam penentuan waktu baku proses produksi YST MP Revo. Hal utama dari CPM adalah bahwa aktivitas yang masuk ke dalam jalur kritis tidak dapat mengalami penundaan penyelesaiannya. Pengecoran logam, misalnya, membutuhkan waktu 89,5 menit sesuai dengan hasil observasi. Aktivitas pengecoran logam tidak dapat dikerjakan melewati durasi yang telah ditentukan untuk menghindari penundaan keseluruhan proses produksi. Sehingga, dengan mengkombinasi kedua metode ini, produktivitas operator dapat ditingkatkan khususnya aktivitas di jalur kritis. Time study technique merupakan salah satu teknik yang digunakan untuk mengukur produktivitas pekerja di bidang konstruksi dan kinerja proyek [24]. Begitu juga sebaliknya, CPM dapat diaplikasikan pada bidang selain proyek (project management) dimana informasi jalur kritis berperan penting untuk mengoptimalkan produktivitas pekerja.

\section{KESIMPULAN}

Hasil penelitian pada YST MP Revo menunjukkan bahwa perlu adanya perbaikan dalam proses produksi. Waktu baku diperoleh 480,05 menit atau setara dengan 8 jam kerja menurut rumus time study. Dibandingkan dengan pendekatan CPM, proses produksi dapat dikerjakan dalam waktu 6 jam karena waktu yang dihitung adalah durasi aktivitas yang masuk kedalam jalur kritis. CPM menyatakan waktu terpendek penyelesaian keseluruhan aktivitas dimana durasi tiap aktivitas di jalur kritis tersebut tidak dapat mengalami keterlambatan. Sementara aktivitas di luar jalur kritis dapat dikerjakan lewat dari durasi yang telah ditentukan sesuai dengan perhitungan Latest Finish-nya. Dari 21 aktivitas produksi, 15 aktivitas masuk ke jalur kritis. Jika perusahaan ingin menambah jumlah produksi, maka produktivitas operator dapat ditingkatkan baik dengan memperhatikan allowances juga pemborosan gerakan dalam melakukan aktivitas. Informasi yang diberikan metode CPM (completion time dan aktivitas di jalur kritis) dapat menjadi masukan dalam membuat keputusan terkait waktu baku maupun waktu siklus tiap aktivitas terutama perbaikan difokuskan kepada aktivitas yang masuk ke dalam jalur kritis.

Penelitian selanjutnya dapat mengkategorikan pekerja berdasarkan usia, jenis kelamin, dan kesehatan mental karena variabel ini memiliki pengaruh signifikan terhadap waktu istirahat yang diperkenankan [2]. Allowances yang sesuai dikombinasikan dengan postur tubuh yang tepat akan memberikan waktu pengerjaan yang lebih efektif. Metode penentuan 3 (tiga) waktu (optimistic, pessimistic, dan most likely time) sebaiknya dihitung karena tiap waktu tersebut telah mempertimbangkan kondisi bekerja seperti cuaca, cahaya, dan peralatan yang digunakan untuk mendapatkan completion time yang lebih akurat. Kedua metode ini dapat juga digabungkan dengan motion study sehingga dapat dianalisis gerakan yang menjadi "waste" berikut dengan penyebab terjadinya kelelahan dari sisi ergonomi. Variabel skill, effort, conditions, dan consistency akan menentukan perhitungan Performance Rating Factor. Hasil penelitian ini dapat menjadi masukan bagi penelitian berikutnya untuk perhitungan waktu normal dan waktu baku yang robust (handal) sesuai dengan kondisi sebenarnya.

\section{DAFTAR PUSTAKA}

[1] M. Akansel, B. Yagmahan, and E. Emel, "Determination of standard times for process improvement: A case study," Glob. J. Business, Econ. Manag. Curr. Issues, vol. 7, no. 1, p. 62, Jun. 2017, doi: 10.18844/gjbem.v7i1.1876.

[2] E. Houshyar and I. J. Kim, "Understanding musculoskeletal disorders among Iranian apple harvesting laborers: Ergonomic and stop watch time studies," Int. J. Ind. Ergon., 2018, doi:10.1016/j.ergon.2018.04.007.

[3] C. Duran, A. Cetindere, and Y. E. Aksu, "Productivity improvement by work and time study technique for earth energyglass manufacturing company," Procedia 
Econ. Financ., vol. 26, pp. 109-113, 2015, doi:10.1016/S2212-5671(15)008874.

F. Asche, K. H. Roll, and R. Tveteras, "Innovations and Productivity Performance in Salmon Aquaculture," Springer, Berlin, Heidelberg, 2012, pp. 620-627, doi: 10.1007/978-3-642-33980$6 \_66$.

[5] A. L. T. Novaes, G. J. P. O. de Andrade, A. dos S. Alonço, and A. R. M. Magalhães, "Operational performance in aquaculture: A case study of the manual harvesting of cultivated mussels," Aquac. Eng., 2019, doi: 10.1016/j.aquaeng.2018.12.006.

[6] E. Saurman et al., "Assessing Program Efficiency: A Time and Motion Study of the Mental Health Emergency Care Rural Access Program in NSW Australia," Int. J. Environ. Res. Public Health, vol. 11, no. 8, pp. 7678-7689, Jul. 2014, doi: 10.3390/ijerph110807678.

[7] A. P. Puvanasvaran, C. Z. Mei, and V. A. Alagendran, "Overall equipment efficiency improvement using time study in an aerospace industry," in Procedia Engineering, 2013, vol. 68, pp. 271-277, doi: 10.1016/j.proeng.2013.12.179.

[8] F. Nabi, R. Mahmud, and M. M. Islam, "Improving Sewing Section Efficiency through Utilization of Worker Capacity by Time Study Technique," Int. J. Text. Sci., vol. 4, no. 1, pp. 1-8, 2015, doi: 10.5923/j.textile.20150401.01.

[9] J. R. Stewart and F. E. Meyers, Motion Time Study for Lean Manufacturing. Englewood Cliffs, NJ: Prentice-Hall, 2002. available at: Google Scholar.

[10] W. Sritomo, Ergonomi Studi Gerak dan Waktu. Surabaya: Guna Widya, 2003. available at: Google Scholar.

[11] K. B. Faria, A. C. D. S. G. dos Santos, L. A. Mendonça, A. D. C. Reis, and S. A. F. Salles, "Influencing factors analysis to determine standard time of operators in a gauge calibration process," Indep. J. Manag. Prod., vol. 9, no. 5, p. 589, Jul. 2018, doi:10.14807/ijmp.v9i5.811.

[12] K. Y. Ferreira García, J. de la Riva Rodriguez, J. Sánchez Leal, R. M. ReyesMartínez, and A. W. Prieto, "Determination of Allowance Time by Work Sampling and Heart Rate in Manufacturing Plant in Juárez México," J. Eng., vol. 2019, pp. 1-6, Mar. 2019, doi: $10.1155 / 2019 / 1316734$.

[13] M. Radujković and M. Sjekavica, "Project
Management Success Factors," Procedia Eng., vol. 196, pp. 607-615, 2017, doi: 10.1016/j.proeng.2017.08.048.

[14] C. E. M. Serra and M. Kunc, "Benefits Realisation Management and its influence on project success and on the execution of business strategies," Int. J. Proj. Manag., vol. 33, no. 1, pp. 53-66, Jan. 2015, doi:10.1016/j.ijproman.2014.03.011. M. F. Nagata, W. A. Manginelli, S. Lowe, and T. J. Trauner, Construction delays. available at: Google Scholar

[16] E. Forcael, V. González, F. Orozco, A. Opazo, Á. Suazo, and P. Aránguiz, "Application of Problem-Based Learning to Teaching the Critical Path Method," J. Prof. Issues Eng. Educ. Pract., vol. 141, no. 3, p. 04014016, Jul. 2015, doi: 10.1061/(ASCE)El.1943-5541.0000236.

[17] D. Satyanegara and F. Nurunnajmi, "Penjadwalan proyek pembangunan jaringan distribusi listrik perdesaan," $J$. Organ. Dan Manaj., vol. 13, no. 1, pp. 3039, 2017. available at: http://www.ilp.ut.ac.id/index.php/JOM/artic le/view/425.

[18] A. Nalhadi and N. Suntana, "Analisa Infrastruktur Desa Sukaci-Baros Dengan Metode Critical Path Method (CPM)," J. Sist. dan Manaj. Ind., vol. 1, no. 1, p. 35, Aug. 2017,doi :10.30656/jsmi.v1i1.167.

[19] D. A. Saputra M, E. Satria, and G. A. Pandy, "Optimalisasi Proses Perakitan Pesawat Tanpa Awak dengan Metoda Critical Path Methods (CPM)," J. Optimasi Sist. Ind., vol. 15, no. 1, p. 87, 2017, doi: 10.25077/josi.v15.n1.p87-92.2016.

[20] K. B. Zandin, MOST work measurement systems. CRC press, 2002. available at: Google Scholar.

[21] S. A. Kumar and N. Suresh, Production and operations management. New delhi: New Age International, 2006. available at: Google Scholar.

[22] L. S. Aft, Work measurement and methods improvement. New York: John Wiley \& Sons, Inc, 2000. available at: Google Scholar.

[23] P. M. Institute and A. N. S. Institute, "A guide to the project management body of knowledge," 2008. available at: Google Scholar.

[24] M. E. Shehata and K. M. El-Gohary, "Towards improving construction labor productivity and projects' performance," Alexandria Eng. J., vol. 50, no. 4, pp. 321-330, Dec. 2011, doi: 10.1016/J.AEJ.2012.02.001. 